\title{
Dual-Energy Perfusion-CT in Recurrent Pancreatic Cancer - Preliminary Results
}

\section{Dual-Energy Perfusions-CT bei Pankreaskarzinomrezidiven - Vorläufige Ergebnisse}

Authors

Affiliations
F. Fritz' , S. Skornitzke' ${ }^{1}$, T. Hackert ${ }^{2}$, H. U. Kauczor ${ }^{1}$, W. Stiller ${ }^{1}$, L. Grenacher ${ }^{3}$, M. Klauss ${ }^{1}$

Clinic of Diagnostic and Interventional Radiology, University of Heidelberg, Germany

Clinic of Surgery, University of Heidelberg, Germany

3 Diagnostic Imaging Center, Diagnostik München, Germany
Key words

- abdomen

- pancreas

- CT

adenocarcinoma

received $\quad 28.12 .2015$

accepted 17.3.2016

\section{Bibliography}

Dol http://dx.doi.org/ 10.1055/s-0042-105765

Published online: 2016

Fortschr Röntgenstr 2016; 188:

559-565 @ Georg Thieme

Verlag KG Stuttgart - New York . ISSN 1438-9029

\section{Correspondence}

Herr Prof. Lars Grenacher Diagnostic Imaging Center, Diagnostik München

Augustenstr. 115

80798 München

Germany

Tel.: ++ 49/89/52055200

Fax: ++49/89/52055203

I.grenacher@diagnostik-

muenchen.de

\section{Zusammenfassung \\ $\nabla$}

Ziel: Beurteilung der diagnostischen Eignung der Dual-Energy (DE) Perfusions-CT zur Differenzierung von postoperativen Weichgewebeformationen und Tumorrezidiven nach potentiell kurativer Pankreaskarzinomresektion.

Material und Methoden: 24 Patienten nach potentiell kurativer Resektion eines Pankreaskarzinoms, die im Rahmen der regulären konventionellen Nachsorge-CT unklare postoperative Weichgewebeformationen aufwiesen, wurden prospektiv eingeschlossen. Die Untersuchung erfolgte an einem 64-Zeilen Dual-Source-CT mittels einer dynamischen Sequenz aus 34 DE-Akquisitionen alle 1,5s ( $80 \mathrm{ml}$ iodhaltiges Kontrastmittel, $370 \mathrm{mg} / \mathrm{ml}$, Fluss $5 \mathrm{ml} / \mathrm{s}$ ). DE Perfusions-Bilddatensätze linear gewichteter $120 \mathrm{kV}$-äquivalenter Mischbilder wurden mit einer Body-Perfusions CT-Applikation (CT Body Perfusion, Siemens Medical Solutions, Germany) zur Berechnung von Blutfluss, Permeabilität und Blutvolumen ausgewertet. Die Diagnose wurde mittels histologischer Sicherung $(n=4)$ bzw. durch weitere, reguläre Verlaufskontrollen bestätigt.

Ergebnisse: Bei 15 Patienten wurden Rezidive eines Pankreaskarzinoms diagnostiziert, 9 Patienten zeigten unspezifische Weichgewebeformationen. Der auf Basis gewichteter, $120 \mathrm{kVp}$-äquivalenter DE Perfusions-Bilddatensätze bestimmte Blutfluss in Rezidiven tendierte zu niedrigeren Werten mit $16,6 \mathrm{ml} / 100 \mathrm{ml} / \mathrm{min}$ vs. $24,7 \mathrm{ml} / 100 \mathrm{ml} / \mathrm{min}$ im Vergleich zu den unspezifischen Weichgewebeformationen, wenn auch nicht signifikant (n.s., $\mathrm{p}=0,06$, Signifikanzniveau 0,05). Permeabilität und Blutvolumen der Rezidive waren nur geringfügig niedriger (n.s.).

Schlussfolgerung: Die DE Perfusions-CT ist eine vielversprechende Methode der funktionellen Bildgebung und scheint für die Diagnostik in der Nachsorge nach Pankreaskarzinomresektion geeignet. Bislang ist nur ein Trend zu niedrigeren Perfusionswerten in Rezidiven im Vergleich zu unspezifi-

\section{Abstract \\ $\nabla$}

Purpose: To evaluate the diagnostic performance of dual energy (DE) perfusion-CT for the differentiation between postoperative soft-tissue formation and tumor recurrence in patients after potentially curative pancreatic cancer resection.

Material and methods: 24 patients with postoperative soft-tissue formation in the conventional regular follow-up CT acquisition after pancreatic cancer resection with curative intent were included prospectively. They were examined with a 64-row dual-source CT using a dynamic sequence of $34 \mathrm{DE}$ acquisitions every $1.5 \mathrm{~s}$ ( $80 \mathrm{ml}$ of iodinated contrast material, $370 \mathrm{mg} / \mathrm{ml}$, flow rate $5 \mathrm{ml} / \mathrm{s}$ ). Weighted average (linearly blended M0.5) 120kVp-equivalent dual-energy perfusion image data sets were evaluated with a body-perfusion CT tool (see above) for estimating blood flow, permeability, and blood volume. Diagnosis was confirmed by histological study $(n=4)$ and by regular follow-up.

Results: Final diagnosis was local recurrence of pancreatic cancer in 15 patients and unspecific postoperative tissue formation in 9 patients. The blood-flow values for recurrence tissue trended to be lower compared to postoperative tissue formation with $16.6 \mathrm{ml} / 100 \mathrm{ml} / \mathrm{min}$ and $24.7 \mathrm{ml} /$ $100 \mathrm{ml} / \mathrm{min}$, respectively for weighted average $120 \mathrm{kVp}$-equivalent image data, which was not significant (n.s.) $(\mathrm{p}=0.06$, significance level 0.05$)$. Permeability- and blood-volume values were only slightly lower in recurrence tissue (n.s.).

Conclusion: DE perfusion-CT is feasible in patients after pancreatic cancer resection and a promising functional imaging technique. As only a trend for lower perfusion values in local recurrence compared to unspecific postoperative alterations was found, the perfusion differences are not yet sufficient to differentiate between malignancy and unspecific postoperative alterations for this new technique. Further studies and technical improve- 
schen, postoperativen Weichgewebeformationen nachzuweisen; die Perfusionsunterschiede reichen aktuell noch nicht aus, um zwischen malignen und unspezifischen, postoperativen Veränderungen zu differenzieren. Weitere Studien sowie technische Verbesserungen sind nötig, um verlässliche Werte für die Beantwortung dieser klinisch hochrelevanten Frage zu erhalten.

Kernaussagen:

- DE Perfusions-CT ist eine machbare Technik nach PankreasKarzinom-Resektion.

Die bislang nicht mögliche Differenzierung zwischen postoperativem Gewebe und Rezidiven erscheint in Reichweite.

$\checkmark$ DE Perfusions-CT hat das Potential heutige Limitationen in der rein morphologischen Diagnostik von PankreaskarzinomRezidiven zu überwinden. ments are needed to generate reliable data for this clinically highly relevant differentiation.

Key points:

$\checkmark$ DE Perfusion CT is feasible in patients after pancreatic cancer resection.

- While reliable differentiation of unspecific postoperative tissue formation from recurrent malignancy cannot be achieved yet, it is within reach.

DE Perfusion CT has the potential to overcome todays limitations of pure morphological diagnosis of recurrent pancreatic cancer.

Citation Format:

- Fritz F, Skornitzke S, Hackert T et al. Dual-Energy Perfusion-CT in Recurrent Pancreatic Cancer - Preliminary Results. Fortschr Röntgenstr 2016; 188: 559-565

\section{Introduction}

Pancreatic cancer is known to have poor prognosis since the majority of patients present with advanced tumor stages at the time of diagnosis, which allows a potentially curative resection in only approximately $20 \%$ of the patients [1]. Following potentially curative resection, isolated local recurrence occurs in one third of the patients $[1,2]$.

In cases of local recurrence without distant metastases, however, patients may benefit from surgery, which was shown to be associated with an additional 15 months median overall survival [3]. Therefore, it is essential to identify local tumor recurrence early as this offers the possibility of recurrence resection, which can be combined with radiotherapy to achieve best results $[4,5]$. To achieve this goal, a close follow-up following pancreatic ductal adenocarcinoma (PDAC) resection is required $[4,6,7]$. The National Comprehensive Cancer Network (NCCN) guidelines recommend a close surveillance with clinical history, physical examination, CA $19-9$ and CT every 3 to 6 months for the first two years and then annually [8].

The major problem in detecting pancreatic cancer recurrence by CT-based follow-up is caused by unspecific postoperative changes with soft-tissue formation that can often barely be differentiated from disease recurrence [9]. Local recurrence is suspected in contrast-enhanced (CE-) CT if there is a visible enlargement of preexisting soft-tissue formations or if new soft-tissue formations appear.

Conventional CECT offers high-resolution imaging and is widely available, safe and fast, but is only a morphology-based imaging method. Using perfusion CT offers the opportunity to get additional functional imaging information of the examined parenchyma with the same high resolution as provided by conventional CT. This implies that quantitative parameters like blood flow of the examined tissue can be quantified. Additionally, perfusion CT can be performed in dual energy mode, which offers image data featuring the enhanced contrast at $80 \mathrm{kVp}$ while having the noise characteristics of an acquisition at $140 \mathrm{kVp}$. Many studies have shown the feasibility and value of perfusion CT and DE perfusion-CT in pancreatic cancer [10-12], but to our knowledge there are so far no publications on the topic of perfusion CT in pancreatic cancer recurrence.

The purpose of our study was to evaluate the possibility of differentiating unspecific postoperative soft-tissue alterations from tumor recurrence in the follow-up of patients after pancreatic cancer resection using DE perfusion-CT.

\section{Material and Methods}

\section{Patient collective}

This prospective study was approved by the Institutional Review Board. Every enrolled patient provided written informed consent with notice about the additional radiation exposure of the perfusion sequences. Inclusion criteria were patients with pancreatic adenocarcinoma preceding resection, who were scheduled for regular follow-up CT at our institution (in-house protocol initiates follow-up three month after resection) and on who conventional CT detected soft-tissue formation in the anatomical area of the preceding operation suggestive of recurrence. Exclusion criteria for perfusion CT were: general contraindications for the application of contrast medium, previous treatment for recurrence of pancreatic carcinoma, inability to reproduce the breathing technique (see below).

The final diagnosis of pancreatic cancer recurrence was made histopathologically after surgery. If no repeat resection was performed the progression of CT- and clinical findings during follow-up served as standard of reference for diagnosing local recurrence.

After primary diagnosis $n=11$ patients in the group of recurrences had Whipple's procedures, $n=2$ had left side pancreatic resection and $n=2$ had total pancreatectomy. In the group of postoperative soft-tissue formations there were $n=6$ Whipple's procedures, $n=1$ left side pancreatic resection and $n=2$ had total pancreatectomy.

In the group of patients with recurrences $\mathrm{R} 0$ resection was achieved in $n=7$ patients, there were $n=14$ T3-stages and $n=1$ T1-stage, $n=14$ had positive lymph node stages. In the group of postoperative soft-tissue formations $\mathrm{R} 0$ resection was achieved in $n=1$ patient, there were $n=9$ T3-stages and $n=6$ positive lymph node stages.

One patient with postoperative soft-tissue formation was enrolled twice in this study, but only the first examination was included in the analysis.

\section{CT imaging}

Prior to the CT acquisition, patients had to drink 1-1.5 liters of water and received $20 \mathrm{mg}$ of hyoscine butylbromide i. v. (Busco$\operatorname{pan}^{\circledR}$, Boehringer, Ingelheim, Germany) [13].

The patients were examined with a 64-row dual-source CT (Siemens Somatom Definition Flash, Erlangen, Germany). First we performed a helical CT-acquisition of the abdomen before and after administration of $80 \mathrm{ml}$ of non-ionic iodinated contrast material 
(370 mg iodine/ml; Ultravist ${ }^{\circledR} 370$, Schering, Berlin, Germany), including at least arterial and venous phases (table 1 ). After conventional CT-acquisition of the upper abdomen, there was a 15 minute break to allow for contrast material to wash-out from the pancreatic parenchyma. During this break the patients remained on the CT table without moving. In order to minimize breathing artefacts during the following dynamic CT-examination, patients were instructed to use a shallow breathing technique.

During the waiting period we defined the localization of the suspicious soft-tissue formation based on the CECT acquisition. A single low-dose acquisition (scan-\&-view) during shallow breathing was used to validate the correctness of the chosen acquisition region,

For the perfusion sequence $80 \mathrm{ml}$ of a non-ionic contrast material (370 mg iodine/ml; Ultravist ${ }^{\circledR} 370$, Schering, Berlin, Germany) was injected through a 16- or 18-gauge catheter in an antecubital vein using a flow rate of $5 \mathrm{ml} / \mathrm{s}$, followed by a chaser bolus of $40 \mathrm{ml}$ saline solution. The perfusion sequence in dual-energy mode was started after a constant delay of 13 seconds with respect to contrast material injection. The dual-energy (DE) technique employed tube voltages of $80 \mathrm{kVp}$ and $140 \mathrm{kVp}$ using tin filtration with effective tube currents of $270 \mathrm{mAs}$ and $104 \mathrm{mAs}$ (CARE Dose 4D, Siemens Medical Solutions, Forchheim, Germany) respectively. The dynamic imaging sequence consisted of 34 acquisitions of $0.5 \mathrm{~s}$ duration (rotation time) every $1.5 \mathrm{~s}$ (cycle time) (total examination time of $51 \mathrm{~s}$ ). The perfusion sequence covered a craniocaudal width of $19.2 \mathrm{~mm}$ (collimation of $32 \times 0.6$, - Table 1) from which three consecutive image slices of $5 \mathrm{~mm}$ slice thickness could be reconstructed for each of the 34 acquisitions (kernel B30 $\mathrm{f}(\mathrm{n}=16)$, B31 $\mathrm{f}(\mathrm{n}=8))$.

\section{Data analysis}

Perfusion data were analyzed utilizing a Body-Perfusion CT-tool (CT Body Perfusion - Workflow Template, Siemens Medical Solutions, Erlangen, Germany) at a multimodality workplace with the syngo.via imaging software (Siemens Medical Solutions, Forchheim, Germany). The CT Body Perfusion application (pancreatic tumors) for appraisal of perfusion data is based inter alia on compartment models. For the estimation of the blood flow value a single-compartment-model (maximum slope) and for blood volume value and flow extraction value a two-compartment model (Patlak) is used $[14,15]$. We evaluated the weighted average (linearly blended M0.5) $120 \mathrm{kVp}$-equivalent examinations of the dual-energy acquisition with a B30 $\mathrm{f}$ kernel $(\mathrm{n}=16)$ or a B31 $\mathrm{f}$ kernel $(n=8)$ to estimate the parameters and parameter maps.
Two radiologists (with twelve years and four years of experience in interpreting abdominal images, respectively) placed polygonal VOIs in the suspicious tissue formation. Therefore, a joint decision for placing the VOI was made, trying to cover as much suspicious tissue as possible without including any vessels. Using a compartment model the software calculated the following parameters, respectively:

perfusion $[\mathrm{ml} / 100 \mathrm{ml} / \mathrm{min}]$

permeability $[\mathrm{ml} / 100 \mathrm{ml} / \mathrm{min}$ and]

- blood volume $[\mathrm{ml} / 100 \mathrm{ml}]$

\section{Radiation exposure}

Effective radiation dose $\left(D_{\text {eff }}\right)$ was calculated for the DE-acquisition of the perfusion sequence including the contribution of both tubes operating at $80 \mathrm{kVp}$ and $140 \mathrm{kVp}$, respectively, as well as for the acquisitions in the context of regular follow-up CT examination. For that purpose, each of the corresponding dose-length-products (DLP) were multiplied with the cor-

$D_{\text {eff }}=\frac{0.015 \mathrm{mSv}}{\mathrm{mGy} \cdot \mathrm{cm}} \times D L P$

responding conversion factor for abdominal CT-examinations $(0.015 \mathrm{mSv} / \mathrm{mGy} \times \mathrm{cm}$ based on ICRP 60 published in 2004) [16]: Thus, the total radiation exposure (RE) of the CT examination is the sum of the effective radiation doses $D_{\text {eff }}$ of the dynamic DEperfusion sequence as well as of the single-energy acquisitions.

\section{Statistical analysis}

For quantitative analysis, the distribution of the patient age and CT-perfusion-parameters was given as mean value with standard deviation and range. The derived perfusion-parameters were tested for significant differences between pancreatic cancer recurrence and unspecific soft tissue using an unpaired t-test, respectively. A significance level of $p<0.05$ was considered statistically significant. Descriptive statistics as well as t-tests were performed using Microsoft ${ }^{\circledR}$ Excel $^{\circledR} 2008$ for Mac, Version 12.3.6. Box-plots were generated using $\mathrm{R}$ ( $\mathrm{R}$ Foundation for Statistical Computing).

Table 1 Protocol of the three-phasic CT-acquisition and the dynamic DECT-perfusion sequence.

Tab. 1 Protokoll der 3-Phasen-CT und der dynamischen DECT-Perfusions-Sequenz.

\begin{tabular}{|c|c|c|c|c|c|c|c|}
\hline phase & $\begin{array}{l}\text { tube potential } \\
{[\mathrm{kVp}]}\end{array}$ & $\begin{array}{l}\text { tube cur- } \\
\text { rent (eff.) } \\
\text { [mAs] }\end{array}$ & $\begin{array}{l}\text { primary } \\
\text { collimation } \\
{[\mathrm{mm}]}\end{array}$ & $\begin{array}{l}\text { slice thick- } \\
\text { ness (recon.) } \\
\text { [mm] }\end{array}$ & $\begin{array}{l}\text { delay } \\
{[\mathbf{s}]}\end{array}$ & $\begin{array}{l}\text { gantry rotation time } \\
\text { [s] }\end{array}$ & $\begin{array}{l}\text { number of } \\
\text { acquisitions }\end{array}$ \\
\hline 1. native & $120^{1}$ & $210^{1}$ & $2 \times 64 \times 0.6$ & $3.0 / 1.5$ & 4 & 0.5 & helical \\
\hline \multicolumn{8}{|c|}{ contrast medium: $80 \mathrm{ml}$ (flow $5 \mathrm{ml} / \mathrm{s}$ ); ROI: abdominal aorta at the level of the coeliac trunk; trigger threshold: $120 \mathrm{HU}$; cycle time: $1.5 \mathrm{~s}$; monitor delay: $10 \mathrm{~s}$} \\
\hline 2. arterial & $120^{1}$ & $210^{1}$ & $2 \times 64 \times 0.6$ & $3.0 / 1.5$ & 10 & 0.5 & helical \\
\hline 3. venous & $120^{1}$ & $210^{1}$ & $2 \times 64 \times 0.6$ & $3.0 / 1.5$ & 40 & 0.5 & helical \\
\hline \multicolumn{8}{|c|}{$\begin{array}{l}15 \text { minutes break: contrast medium clearance - patient remaining on the CT table } \\
\text { contrast medium: } 80 \mathrm{ml} \text { with } 40 \mathrm{ml} \text { saline solution chaser (flow } 5 \mathrm{ml} / \mathrm{s} \text { ) }\end{array}$} \\
\hline 4. perfusion & Sn $140 / 80$ & $104 / 270$ & $32 \times 0.6$ & $3 \times 5.0$ & 13 & $\begin{array}{l}0.5 \text { (full rotation) } \\
1.5 \text { (cycle time) }\end{array}$ & 34 dynamic \\
\hline
\end{tabular}

$k V p=$ peak kilovoltage; $m A s=$ milliampere-second; eff. = effective; $m m$ = millimeter; $m \mathrm{l}=$ milliliter; recon. = reconstructed; $s=$ second; $\mathrm{HU}=\mathrm{Hounsfield}$ Units; $\mathrm{Sn}=$ tin filtration, Siemens; 1 plus CARE Dose 4D and CARE kV, Siemens. 


\section{Results}

$\nabla$

The study population consisted of 24 patients ( 16 men, 8 women) (mean age 66.2 years; range: 48 - 83). The mean follow-up period in the group of postoperative soft tissue formation was 42.4 months. During this period no suspicious growth was detected in the regular follow-up CT. In the group with pancreatic cancer recurrence mean follow-up was 14.7 months.

DECT perfusion was feasible and could be evaluated in all 24 patients. The final diagnosis was local recurrence of pancreatic cancer in 15 patients. In nine patients postoperative soft-tissue formation without local recurrence was diagnosed. Out of the 15 patients with recurrence histological proof of local recurrence was available in four patients, while the remaining 11 patients showed typical symptoms of progressive disease in the further follow-up confirming the diagnosis. The mean diameter of the recurrent tissue formations was $1.9 \times 2.5 \mathrm{~cm}$, while the diameter of the non-tumorous postoperative tissue averaged $1.2 \times 2.1 \mathrm{~cm}$.

In $\odot$ Fig. 1 the box-plot exemplifies the data points of the blood flow in recurrence versus postoperative soft-tissue formations.

The mean values with standard deviation for blood flow, permeability and blood volume in recurrence and unspecific postoperative tissue formations for weighted average $120 \mathrm{kVp}$-equivalent DE image data are visualized in $\bullet$ Fig. 2, 3 and summarized in $\bullet$ Table 2.

The blood-flow values for recurrence tissue were lower compared to postoperative soft tissue with a range from [8.4-29.9] ml/ $100 \mathrm{ml} / \mathrm{min}$ for weighted average $120 \mathrm{kVp}$-equivalent image data in recurrence and a range from $[9.9-66.9] \mathrm{ml} / 100 \mathrm{ml} / \mathrm{min}$ for weighted average $120 \mathrm{kVp}$-equivalent image data in postoperative soft-tissue formation. These differences did not reach statistical significance $(\mathrm{p}=0.06)$.

Mean permeability values were lower in recurrence tissue compared to postoperative soft tissue with a range from [0.9-17.1] $\mathrm{ml} / 100 \mathrm{ml} / \mathrm{min}$ and $[1.6-29.7] \mathrm{ml} / 100 \mathrm{ml} / \mathrm{min}$ for weighted average $120 \mathrm{kVp}$-equivalent image data (n.s.).

The blood volume values were nearly the same in recurrence and postoperative soft tissue (range: $0.1-6.2 \mathrm{ml} / 100 \mathrm{ml}$ and $0.04-$ $5.96 \mathrm{ml} / 100 \mathrm{ml}$ ) for weighted average $120 \mathrm{kVp}$-equivalent image data (n.s.; $\odot$ Table 2 ).

\section{Radiation exposure}

The mean total radiation exposure (DLP) for the entire CT examination (regular follow-up CT plus dynamic perfusion sequence) was $1248.9 \mathrm{mGy} \times \mathrm{cm}\left(\mathrm{D}_{\text {eff }}(\right.$ total $\left.)=18.7 \mathrm{mSv}\right)$ subdivided in $598.8 \mathrm{mGy} \times \mathrm{cm}\left(\mathrm{D}_{\text {eff }}(\mathrm{DECT}\right.$ perfusion $\left.)=9.0 \mathrm{mSv}\right)$ for the perfusion sequence [range $258-761 \mathrm{mGy} \times \mathrm{cm}\left(\mathrm{D}_{\text {eff }}=3.9-11.4 \mathrm{mSv}\right.$ ] and $650.1 \mathrm{mGy} \times \mathrm{cm}\left(\mathrm{D}_{\text {eff }}(3\right.$-phase $\left.\mathrm{CT})=9.7 \mathrm{mSv}\right)$ for the regular follow-up CT [range $260-1362 \mathrm{mGy} \times \mathrm{cm}\left(\mathrm{D}_{\text {eff }}=3.9-20.4 \mathrm{mSv}\right.$ ]. In line with the regular follow-up acquisitions all patients had ar-

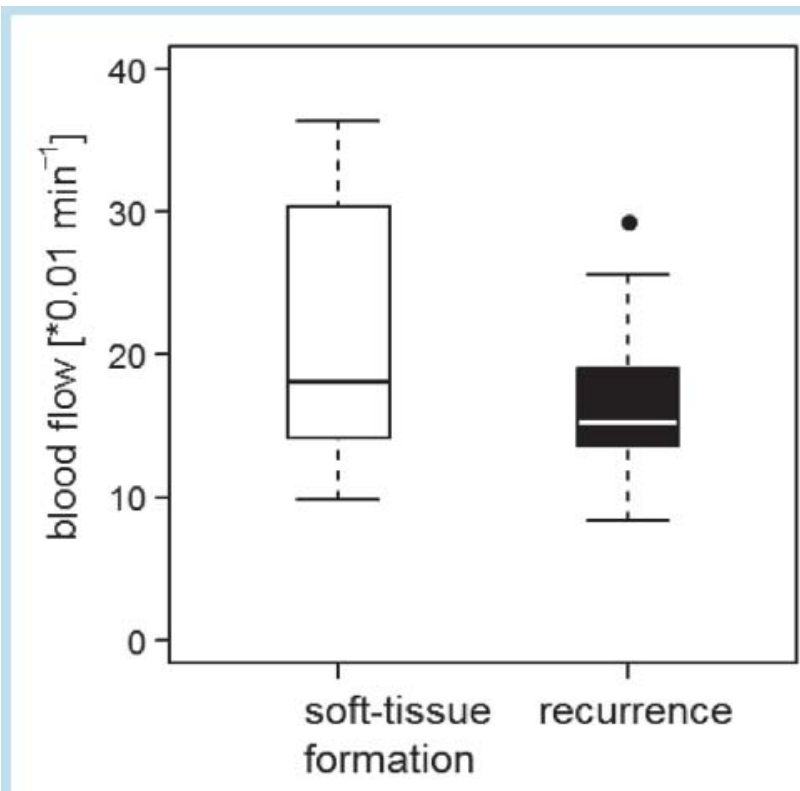

Fig. 1 Boxplots showing the distribution of blood flow values in postoperative non-tumorous tissue and recurrence. Shown are median, upper and lower quartiles, whiskers and outliers.

Abb. 1 Der Boxplot zeigt die Verteilung der Werte für den Blutfluss in postoperativem Narbengewebe und in Rezidiven. Dargestellt sind der Median, oberes und unteres Quartil, die beiden Extremwerte/Whisker und die Ausreißer.
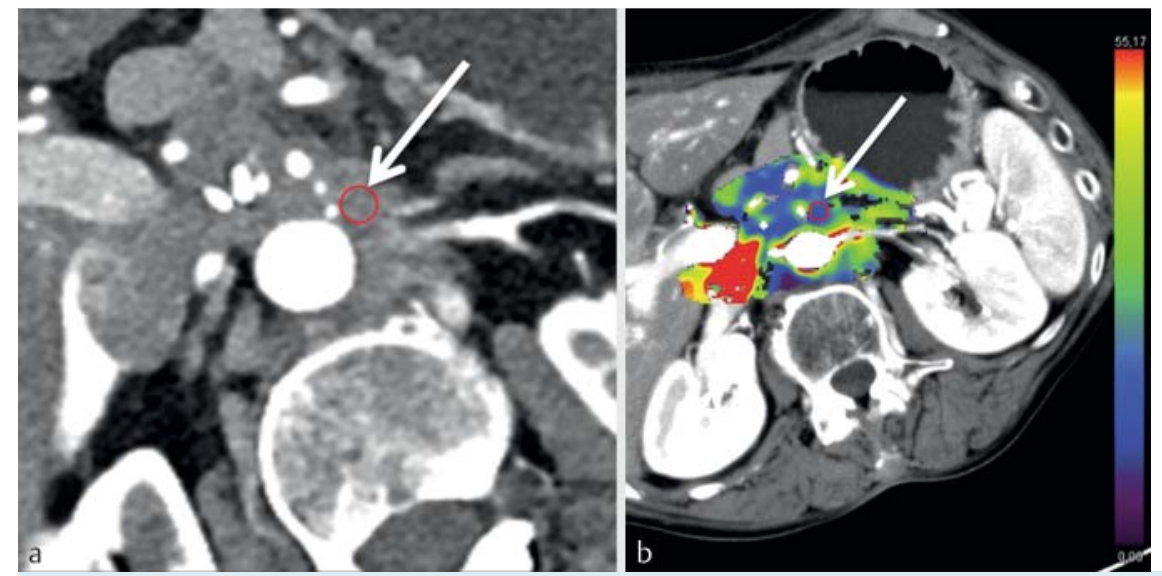

Fig. 2 Arterial phase a and color-coded parameter map for blood flow values derived from perfusion-sequence $\mathbf{b}$ show an example of relapse of pancreatic cancer with soft tissue surrounding the superior mesenteric artery (arrow). In the color-coded parameter map b for blood flow values purple/ blue represent low blood flow values, while yellow/red represent high blood flow values. The corresponding blood flow values in the malignant postoperative soft tissue were $16.3 \mathrm{ml} / 100 \mathrm{ml} / \mathrm{min}$ (identified with the red circle).
Abb. 2 Arterielle Phase a und farbkodierte Parameterkarte der Werte für den Blutfluss, berechnet aus der Perfusionssequenz $\mathbf{b}$ zeigen ein Beispiel für ein Pankreaskarzinomrezidiv mit Weichgewebe, das die Arteria mesenterica superior ummauert (Pfeil). In der farbkodierten Parameterkarte der Werte für den Blutfluss b stellen violette/blaue Farbtöne niedrige und gelbe/rote Farbtöne hohe Blutflüsse dar. Der entsprechende Wert des Blutflusses des Rezidivs war $16,3 \mathrm{ml} / 100 \mathrm{ml} / \mathrm{min}$ (roter Kreis). 

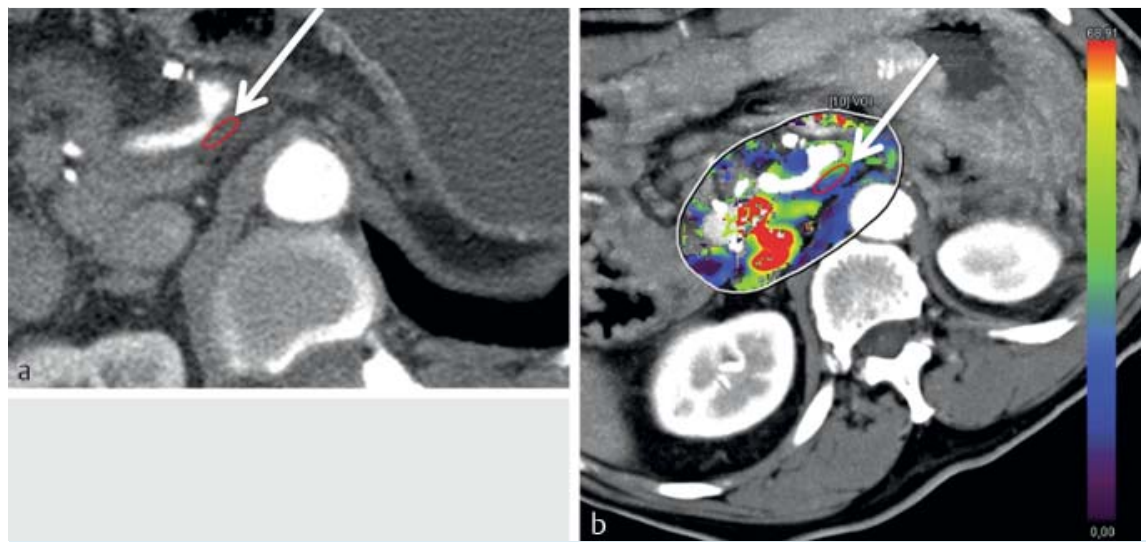

Fig. 3 Arterial phase a and color-coded parameter map for blood flow values derived from perfusion-sequence $\mathbf{b}$ show an example of non-tumorous postoperative soft-tissue formation after pancreatic cancer-resection with soft tissue surrounding the hepatic artery (arrow). In the color-coded parameter map b for blood flow values purple/blue represent low blood flow values, while yellow/red represent high blood flow values. The corresponding blood flow values in the postoperative tissue were $37.4 \mathrm{ml}$ $100 \mathrm{ml} / \mathrm{min}$ (identified with the red ellipse).
Abb.3 Arterielle Phase a und farbkodierte Parameterkarte der Werte für den Blutfluss, berechnet aus der Perfusionssequenz $\mathbf{b}$ zeigen ein Beispiel für ein postoperatives Narbengewebe um die Arteria hepatica (Pfeil). In der farbkodierten Parameterkarte der Werte für den Blutfluss b stellen violette/ blaue Farbtöne niedrige und gelbe/rote Farbtöne hohe Blutflüsse dar. Der entsprechende Wert des Blutflusses des Narbengewebes war $37,4 \mathrm{ml} /$ $100 \mathrm{ml} / \mathrm{min}$ (rote Ellipse).
Table 2 Mean values with standard deviation of blood flow, permeability and blood volume for recurrence and postoperative soft-tissue formation after pancreatic cancer resection at average weighted $120 \mathrm{kV}$ p examinations.

Tab. 2 Mittelwert mit Standardabweichung des Blutflusses, der Permeabilität und des Blutvolumens in Rezidiven und postoperativen Weichgewebeformationen nach Pankreaskarzinomresektion in gewichteten, $120 \mathrm{kVp}$ äquivalenten DE Perfusions-Bilddatensätzen.

\begin{tabular}{llcl} 
& $\begin{array}{l}\text { blood flow } \\
{[\mathbf{m l} / \mathbf{1 0 0} \mathbf{m l} / \mathbf{m i n}]}\end{array}$ & $\begin{array}{l}\text { Permeability } \\
{[\mathbf{m l} / \mathbf{1 0 0} \mathbf{m l} / \mathbf{m i n}]}\end{array}$ & $\begin{array}{l}\text { blood volume } \\
{[\mathbf{m l} / \mathbf{1 0 0 m l}]}\end{array}$ \\
\hline $\begin{array}{l}16.6 \pm 6.0 \\
\text { recurrence } \\
\text { tissue }(\mathrm{n}=15)\end{array}$ & $8.7 \pm 4.0$ & $2.3 \pm 1.6$ \\
\hline $\begin{array}{l}\text { postoperative } \\
\text { soft tissue } \\
(n=9)\end{array}$ & $24.7 \pm 18.1$ & $10.7 \pm 9.3$ & $2.8 \pm 1.8$ \\
\hline \begin{tabular}{l} 
p-value \\
\hline
\end{tabular} & 0.06 & 0.23 & 0.25 \\
\hline
\end{tabular}

$\mathrm{ml}=$ milliliter; $\min =$ minute .

terial and venous phases, $\mathrm{n}=11$ also had non-enhanced phases, $\mathrm{n}=9$ had additional venous chest CT and $\mathrm{n}=5$ patients had late venous phases due to inexplicit lesions.

\section{Discussion}

In the present study, dual source dual energy CT perfusion has been used for the first time to differentiate local disease recurrence from unspecific soft-tissue alterations in patients after pancreatic cancer resection. We found that while local disease recurrence shows lower blood flow than postoperative soft-tissue formation, there was a considerable overlap between both groups.

Local recurrence of pancreatic cancer occurs in $80 \%$ of patients within 2 years after potentially curative resection [17]. Patients with isolated local recurrence of pancreatic cancer show a survival benefit when repeat resection [3] with or without radiotherapy can be performed [18], and should therefore be identified early during follow-up. One of the most difficult radiological challenges in this context is the differentiation between unspe- cific postoperative soft-tissue alterations and true recurrence at an early stage with conventional imaging modalities.

In some cancer centers, postoperative follow-up with PET-CT imaging after pancreatic cancer resection is performed under the assumption that this imaging method is superior in identifying pancreatic cancer relapse compared to CECT $[19,20]$. This is, however, a costly and not widely available method. Consequently, a postoperative follow-up protocol including regular CECT and tumor marker measurement as a cost-effective standard is used in most centers, and PET-CT is performed only in cases of inconclusive CT and tumor marker/clinical findings [4]. A new complementary CT technique providing additional functional information on the examined tissue, such as CT perfusion and dual-energy CT could overcome the disadvantage of CECT compared to PET-CT, with the benefit of greater availability and lower costs. Dual-energy CT and perfusion-CT as well as the combination thereof are expected to improve the diagnosis of pancreatic cancer [11, 21 - 23]. Using perfusion-CT, the analysis of temporal changes of attenuation (in Hounsfield units [HU]) allows assessing the vascular supply of tumors. The derived blood flow values correlate with the histopathologically determined microvessel density in pancreatic neuroendocrine tumors [24]. Dual-energy CT offers the possibility of a simultaneous data acquisition using different photon spectra (usually at $80 / 100 \mathrm{kVp}$ and $140 \mathrm{kVp}$ ) of distinctly different mean energies during a single helical acquisition [25]. The thereby derived weighted average $120 \mathrm{kVp}$-equivalent image data combine the advantages of increased (iodine) contrast at $80 \mathrm{kVp}$ with the low noise at $140 \mathrm{kVp}$, and could thus improve the delineation of perfusion differences between pancreatic cancer recurrence and postoperative soft-tissue alterations.

One previous dual-energy perfusion-CT study in pancreatic cancer showed the potential of dual-energy perfusion-CT in patients with pancreatic carcinoma by more accurate measurements compared to single-energy perfusion-CT [11].

Our findings of non-significantly reduced blood-flow values in pancreatic cancer recurrence tissue compared to non-tumorous postoperative soft tissue tend to match the results of CT perfusion studies evaluating primary pancreatic cancer. These studies reported reduced blood flow in pancreatic adenocarcinomas 
compared to healthy pancreatic tissue both in dual-energy perfusion-CT as well as single-energy perfusion-CT [12]. Our findings suggest that local pancreatic cancer regrowth induces changes leading to a reduced tissue-perfusion, similar to primary pancreatic cancer growing in healthy pancreatic tissue. Histopathologically confirmed pancreatic cancer recurrences show similar changes as primary pancreatic tumors with desmoplasticly altered tissue with fibrous stroma and epithelioid tumor cells [26], which explain a reduced blood flow in these lesions.

Compared to the reported blood-flow values of pancreatic cancer in previous dual-energy and single-energy studies, the bloodflow values of local recurrence of pancreatic cancer in our study were even lower, with mean values of $17 \pm 6 * 0.01 \mathrm{~min}^{-1}$ vs. $27 \pm 4$ *0.01 $\mathrm{min}^{-1}$ and $32 \pm 28 * 0.01 \mathrm{~min}^{-1}[10,11]$. This can be explained by the perfusion characteristic of the underlying environmental tissue in which the respective lesions develop.

As both postoperative soft tissue and pancreatic recurrence tissue have very low blood volume values we could not find significant differences between the two.

The permeability values in pancreatic cancer recurrence compared to non-tumorous postoperative soft tissue were in the same range with a slight trend towards lower permeability values in cancer regrowth. This finding again matches the results of the comparison between pancreatic cancer and healthy pancreatic tissue. The values tended to be lower in pancreatic cancer, but without significant difference and a wide range in values [11, 12]. In earlier perfusion-CT studies, permeability values for local recurrence of pancreatic cancer compared to primary pancreatic cancer were clearly lower which is in line with the finding of the present study. We found a mean permeability of approximately one-fourth of the reported permeability-values in pancreatic cancer tissue $[11,12]$.

A limitation of the study is the small number of patients without local recurrence of pancreatic cancer. Further studies including more patients are needed to confirm the trend we found between recurrence and non-tumorous postoperative soft tissue.

Secondly we did not obtain histological confirmation of the suspected recurrence in all patients. The local recurrences that were diagnosed by further signs of progression in the following examinations already showed a measureable progression in size compared to former CT at the time of examination with the perfusion-CT-protocol. Nevertheless, it is possible that the soft-tissue formation at the time of examination with the perfusion-protocol was not representative for recurrent malignant tissue in the perfusion-CT. Therefore an overestimation of local recurrence in this study is possible. Further studies with regular integration of dual-energy-/perfusion-imaging could solve this problem by recording functional parameters during the course of follow-up, but significant dose-reduction would thus be required.

Furthermore, there was no histological confirmation in patients with unspecific postoperative soft-tissue formation due to the corresponding small alterations, which are not easily accessible for puncture, for example. However, we supposed a comparatively long period of follow-up without any signs of progression in these patients long enough to assume that these changes do not have primary malignant behaviour.

In conclusion, dual-energy perfusion $\mathrm{CT}$ is feasible in patients after pancreatic cancer resection and is a promising functional imaging technique. As we only found a trend to lower perfusion values in local recurrence compared to unspecific postoperative tissue alterations, the perfusion differences between both tissues are not yet sufficient to allow a clear distinction. Further studies including larger patient collectives and technical improvements are needed to achieve reliable data for this differentiation.

\section{Acknowledgements}

This research was supported by the German Research Foundation (DFG) within project R02 entitled "Innovative Imaging of Tissue Perfusion" of the Transregional Collaborative Research Center SFB/TRR 125 "Cognition-guided Surgery".

\section{References}

1 Vincent A, Herman J, Schulick R et al. Pancreatic cancer. Lancet 2011; 378: $607-620$

2 Van den Broeck A, Sergeant G, Ectors $N$ et al. Patterns of recurrence after curative resection of pancreatic ductal adenocarcinoma. European journal of surgical oncology: the journal of the European Society of Surgical Oncology and the British Association of Surgical Oncology 2009; 35: 600-604

3 Strobel 0 , Hartwig $W$, Hackert $T$ et al. Re-resection for isolated local recurrence of pancreatic cancer is feasible, safe, and associated with encouraging survival. Annals of surgical oncology 2013; 20: 964-972

4 Heye T, Zausig $N$, Klauss $M$ et al. CT diagnosis of recurrence after pancreatic cancer: is there a pattern? World journal of gastroenterology: WJG 2011; 17: $1126-1134$

5 Kleeff J, Reiser C, Hinz U et al. Surgery for recurrent pancreatic ductal adenocarcinoma. Annals of surgery 2007; 245: 566-572

6 Sheffield KM, Crowell KT, Lin YL et al. Surveillance of pancreatic cancer patients after surgical resection. Annals of surgical oncology 2012; 19: $1670-1677$

7 Tzeng CW, Fleming JB, Lee JE et al. Yield of clinical and radiographic surveillance in patients with resected pancreatic adenocarcinoma following multimodal therapy. HPB: the official journal of the International Hepato Pancreato Biliary Association 2012; 14: 365-372

8 Uka K, Aikata H, Takaki S et al. Similar effects of recombinant interferon-alpha- $2 \mathrm{~b}$ and natural interferon-alpha when combined with intraarterial 5-fluorouracil for the treatment of advanced hepatocellular carcinoma. Liver Int 2007; 27: 1209-1216

9 Lepanto L, Gianfelice D, Dery R et al. Postoperative changes, complications, and recurrent disease after Whipple's operation: CT features. American Journal of Roentgenology 1994; 163: 841 - 846

10 Kandel S, Kloeters C, Meyer H et al. Whole-organ perfusion of the pancreas using dynamic volume $\mathrm{CT}$ in patients with primary pancreas carcinoma: acquisition technique, post-processing and initial results. Eur Radiol 2009; 19: 2641 - 2646

11 Klauss M, Stiller W, Pahn G et al. Dual-energy perfusion-CT of pancreatic adenocarcinoma. European journal of radiology 2013; 82: 208 - 214

$12 \mathrm{Xu}$ J, Liang Z, Hao S et al. Pancreatic adenocarcinoma: dynamic 64-slice helical CT with perfusion imaging. Abdom Imaging 2009; 34: 759-766

13 Klauss M, Mohr A, von Tengg-Kobligk $H$ et al. A new invasion score for determining the resectability of pancreatic carcinomas with contrastenhanced multidetector computed tomography. Pancreatology 2008; 8: $204-210$

14 Patlak CS, Blasberg RG, Fenstermacher JD. Graphical evaluation of blood-to-brain transfer constants from multiple-time uptake data. J Cereb Blood Flow Metab 1983; $3: 1-7$

15 Miles KA. Measurement of tissue perfusion by dynamic computed tomography. Br J Radiol 1991; 64: 409-412

16 Shrimpton P. Assessment of patient dose in CT. In, European guidelines for multislice computed tomography funded by the European Commission 2004: contract number FIGMCT2000-20078-CT-TIP Luxembourg: European Commission; 2004

17 Smeenk HG, Tran TC, Erdmann J et al. Survival after surgical management of pancreatic adenocarcinoma: does curative and radical surgery truly exist? Langenbeck's archives of surgery/Deutsche Gesellschaft fur Chirurgie 2005; 390: 94-103

18 Habermehl D, Brecht IC, Bergmann F et al. Chemoradiation in patients with isolated recurrent pancreatic cancer - therapeutical efficacy and probability of re-resection. Radiat Oncol 2013; 8: 27

19 Asagi A, Ohta K, Nasu J et al. Utility of contrast-enhanced FDG-PET/CT in the clinical management of pancreatic cancer: impact on diagnosis, 
staging, evaluation of treatment response, and detection of recurrence. Pancreas 2013; 42: 11-19

20 RufJ, Lopez Hanninen E, Oettle H et al. Detection of recurrent pancreatic cancer: comparison of FDG-PET with CT/MRI. Pancreatology 2005; 5: $266-272$

21 Klauss M, Stiller W, Fritz F et al. Computed tomography perfusion analysis of pancreatic carcinoma. J Comput Assist Tomogr 2012; 36: 237 242

22 Skornitzke S, Fritz F, Klauss $M$ et al. Qualitative and quantitative evaluation of rigid and deformable motion correction algorithms using dual-energy CT images in view of application to CT perfusion measurements in abdominal organs affected by breathing motion. Br J Radiol 2015; 88: 20140683

23 Stiller W, Skornitzke S, Fritz F et al. Correlation of Quantitative Dual-energy CT Iodine Maps and Abdominal CT-perfusion Measurements: Are
Single-acquisition DECT Iodine Maps More Than a Reduced-dose Surrogate of Conventional CT Perfusion? Invest Radiol 2015; 50 In print

24 d'Assignies G, Couvelard A, Bahrami S et al. Pancreatic endocrine tumors: tumor blood flow assessed with perfusion CT reflects angiogenesis and correlates with prognostic factors. Radiology 2009; 250: 407 416

25 Fletcher JG, Takahashi N, Hartman R et al. Dual-energy and dual-source CT: is there a role in the abdomen and pelvis? Radiol Clin North Am 2009; 47: $41-57$

26 Hishinuma S, Ogata Y, Tomikawa M et al. Patterns of recurrence after curative resection of pancreatic cancer, based on autopsy findings. Journal of gastrointestinal surgery: official journal of the Society for Surgery of the Alimentary Tract 2006; 10: 511-518 